How to cite this article:

Ganapathy, M., Tan, D. A. L., \& Phan, J. (2020). Students' perceptions of teachers' written corrective feedback in the Malaysian ESL classroom. Malaysian Journal of Learning and Instruction, 17(2), 103-136. https://doi.org/10.32890/ mjli2020.17.2.4

\title{
STUDENTS' PERCEPTIONS OF TEACHERS' WRITTEN CORRECTIVE FEEDBACK IN THE MALAYSIAN ESL CLASSROOM
}

\author{
${ }^{1}$ Malini N. G. Ganapathy, ${ }^{2}$ Debbita Tan Ai Lin, \& \\ ${ }^{3}$ Jonathan Phan \\ ${ }^{1-3}$ School of Languages, Literacies and Translation \\ Universiti Sains Malaysia, Malaysia
}

${ }^{2}$ Corresponding author:debbita_tan@usm.my

Received: 3/10/2019 Revised: 28/4/2020 Accepted: 17/5/2020 Published: 31/7/2020

\section{ABSTRACT}

Purpose - This study examined the types of written corrective feedback provided to ESL students in writing classes in Malaysian secondary schools, and their perceptions towards the provision of written corrective feedback in the Malaysian context.

Methodology - A survey questionnaire was administered randomly among 720 Form Four students from 10 secondary schools in Penang. The questionnaire was based on a Likert scale and responses were analysed using descriptive statistics.

Findings - Results showed that most learners benefited from and preferred direct feedback, and tended to focus on form such as grammar, paragraph organisation, content and clarity of ideas. Students preferred this form of feedback as they were able to understand errors more clearly. It was found that most students were unable to self-regulate their own errors; a majority could not locate their own errors and had become passive learners within the Malaysian schooling system. 
Significance - The study is significant to Malaysian secondary schools in its effects, depicting the many forms of corrective feedback available in the ESL context that can be employed in school besides the popularized direct feedback used within the syllabus.

Keywords: Second language (L2) pedagogy, written corrective feedback (WCF), second language acquisition (SLA), types of feedback, perception of feedback.

\section{INTRODUCTION}

In second language (L2) pedagogy, much emphasis is placed on linguistic form to ensure the effectiveness of second language acquisition (SLA). Long (2000) advocated the focus-on-form approach, which highlights linguistic elements in the context of lessons that focus on communicating or meaning-making (Long, 2000). Focus-on-form is a popular and suitable strategy of intervention in SLA (Long 2000; Long \& Robinson, 1998). According to Doughty (2003), language acquisition without attention to linguistic form becomes less successful and slower due to the increasing difficulty.

The term 'feedback' refers to "information that is given to the learner about his or her performance on a learning task, usually with the objective of improving the performance" (Ur, 1996, p. 242). Meanwhile, written corrective feedback (WCF) refers to "... any feedback provided to a learner, from any source, that contains evidence of learner error of language form" (Russell \& Spada, 2006, p. 134). Using feedback to teach can be as impactful as instruction quantity and quality, making it one of the key factors in learning (Hattie, 1999). According to Hattie and Timperley (2007), feedback occurs when information on a learner's understanding of their linguistic errors or language performance is relayed to them by an agent - the teacher, a book, or even their own experience. Based on behaviourist and communicative advances in language pedagogy, the purpose of providing feedback is to motivate learners and ensure their linguistic accuracy (Ellis, 2009). Voerman, Meijer, Korthagen and Simons (2012) are of view that the teacher provides information pertaining to the students' understanding or performance in order to improve their learning experience, which is the main goal of providing feedback. Similar terms used to describe feedback include grammar or error correction (Truscott, 1996, 2007). 
Corrective feedback is a long-standing educational practice which has been debated in the L2 context for several decades (Evans, Hartshorn, McCollum, \& Wolfersberger, 2010; Hattie \& Timperley, 2007). Since the 1970s, there has been a debate on the importance of error correction, which has caused a rift in the field of ESL teaching, learning and writing. Specifically, it is uncertain whether error correction is useful, with varying positions taken on its effectiveness (Amrhein \& Nasaji, 2010). Although WCF seems to be supported in many studies, the types of corrective feedback found to be the most beneficial to learners are still unclear in regards to language features.

Past studies on WCF have focussed on its effects on improving accuracy in writing, with some research providing evidence that discredit those studies too. Scholars such as Truscott (2007), Sheppard (1992), and Kepner (1991) claim that corrections to one's grammar can have a negative effect on the learner's L2 writing accuracy growth. At the extreme end, Truscott believes that error correction is inadequate, vain and detrimental to the learner's fluency and overall writing quality, arguing that feedback is theoretically wrong and practically impossible, and also boldly underestimating the advantages of feedback. Research has found no positive effects for L2 error correction due to the teacher's limitation and the student's inattention; these two factors deny the advantages of grammar correction as less focus is placed on other crucial writing concerns (Truscott, 1996, 1999, 2004, 2007, 2009, 2010).

The main criticism of WCF is that teachers often provide written feedback in the form of decontextualized grammar - grammar is taught out of context from its authentic use and communicative settings. When it comes to correcting errors, the teacher usually modifies the student's language based on their own judgement in determining what the students intend to portray. However, the teacher may make incorrect assumptions and end up misinterpreting what the student initially wanted to say (Ferris, 1995; Gass \& Selinker, 1994; Zamel, 1985). This situation places learners at a disadvantage when attempting to put their L2 skills and knowledge to actual use. Past studies have also shown that learners are not aware of what they need to do with their teacher's feedback as they do not fully comprehend their own errors. Students often face difficulty understanding the WCF given, and end up not using the WCF for their own benefit as intended by their teacher (Ferris, 1995; Hyland, 1998). 
According to Dlaska and Krekeler (2013), feedback requires three aspects of information to be effective: 1) the learner's prevailing performance in relation to the intended goal, 2) the intended level of performance; and 3) the solution to bridge the prevailing and intended performance levels. As such, corrective feedback (CF) is thought to be beneficial for SLA as it allows learners to pick up grammatical features that may be lost due to the discontinued access to learning standards (Ellis, 2009).

Form-focussed feedback is advantageous in assisting transferappropriate learning - when one performs a certain action related to language learning, the cognitive process employed by the task should mimic the actual language used for communication (Lyster, 2007; Segalowitz, 2000). Grammar-based interventions are also beneficial in terms of flexibility; they can be in planned, unplanned, or even reactive forms (Basturkmen \& Loewen, 2002). Nonetheless, the effectiveness of the aforementioned approach is only guaranteed if it is carried out in a communicative setting. By understanding the individual needs of the student (e.g., being weak or highly proficient in their L2, educational background, experience or context of teaching) and administering the appropriate type of feedback, teachers help students become more aware of their corrections and internalize them better, due to improved communication between the teacher and the student (Chandler, 2003; Karim, 2013; Bal-Gezegin, 2015; Faqeih, 2015).

Given that CF can be adapted to suit any teaching situation, Sheen (2011) notes that feedback is given in both formal (the teacher or other peers provide the feedback) and informal learning (everyday use by other L1 or L2 speakers). Bellon, Bellon and Blank (1992) claim that the proper use of CF can help learners achieve their desired linguistic performance, on par with the top 20 percent of their peers. This is because of the strong and consistent relationship between academic feedback and achievement, despite the factors of academic performance, socio-economic status, cultural and educational background. By knowing what $\mathrm{CF}$ is and how to apply it in ESL classrooms, the teacher is able to identify each student's strengths, weaknesses and preferences based on the type of $\mathrm{CF}$ given. Nonetheless, Faqeih (2015) is of view that that learners' attitude towards error correction may differ due to their cultural and educational backgrounds.

Depending on the nature of feedback for each learner's writing, preferences and perceptions towards WCF may be partly influenced 
by the feedback itself. Believing that the feedback provided is helpful, the learner will consequently become more motivated to use their desired WCF to identify their errors and make corrections. This in turn will cause learners to be more attentive to their errors, as opposed to those who disagree with the given feedback (McCargar, 1993; Schulz, 2001). Research on WCF has shown that each learner's preference for written feedback is varied; some studies suggest that learners prefer a lot of varied WCF to identify their errors (Ferris, 1995; Lee, 2005), whereas counter-studies have provided evidence that learners prefer comments that focus on content and ideas instead of grammar and form (Woroniecka, 1998, Zamel, 1985). Some students may prefer both specific and non-specific WCF. Lee (2005) for example, found that while students were receptive to overt correction and indirect WCF (e.g., coding), they also preferred comprehensive WCF over selective WCF.

The teacher is responsible for providing the best form of WCF to students, and it is especially so in the Malaysian ESL classroom since many students struggle more with writing than other language skills (i.e., reading, speaking and listening). Based on the Malaysian Education Blueprint 2013-2025, up to 50 percent of students who sat for their final examination were unable to write according to basic Cambridge standards (Ministry of Education Malaysia, 2013). These students would then face challenges in securing a job as employers seek candidates who can write well in English (Nair et al., 2012). The current study is relevant in addressing the issue of students needing to write good English upon graduating secondary school as it sheds new light on the current WCF practices in the Malaysian ESL writing classroom. The objectives of the study are as follows:

1. To determine the types of WCF that are provided to secondary school students in the Malaysian ESL classroom.

2. To examine students' responses and perceptions towards the provision of WCF.

\section{LITERATURE REVIEW}

Studies on feedback with regards to the acquisition of second language writing have been on the rise ever since Ferris (2003) introduced the L2 writing instruction approach in the 1980s. They 
have essentially explored corrections made by individual students in texts, focusing on grammar and error correction (Ferris et al., 2013; Shintani et al., 2014). Although previous studies (Fathman \& Whalley, 1990; Ferris \& Roberts, 2001) have demonstrated that learners could use WCF to correct their own errors in the process of rewriting their drafts, Truscott (1996) claims that learning evidence is unestablished considering that learners are expected to use direct CF (a form of WCF) to straightforwardly copy the given corrections; therefore, the idea of WCF is impractical for learning L2 writing. This is supported by Evans, Hartshorn and Tuioti (2010) who found that despite using WCF, learners still identified grammatical errors as their greatest struggle. Generally, the amount and kind of WCF that is suitable for each individual is still unclear as past research on the practicality of different types of WCF has demonstrated varied results (Amrhein \& Nasaji, 2010).

\section{Types of Feedback and their Effects on Learners}

Inspired by Truscott (1996), several researchers have undertaken new programmes of exploring the different effects of diverse types of CF, i.e., Direct CF, Indirect CF, Focused CF, Unfocused CF, Metalinguistic CF and Electronic CF (Ellis, 2009).

The first two theoretical paradigms mentioned regarding corrective feedback are the cognitive-interactionist and sociocultural perspectives. In any human interaction, the cognitive-interactionist view takes both internal and external factors into account. Learners interact with their environment to obtain information, which in turn activates their internal cognitive processes related to language use. In contrast, the sociocultural view does not distinguish between the environment and the mind. According to Ellis and Shintan (2014), the paradigm not only sees interaction itself as the site for learning, but also views learners' errors as attempts at self-regulation, known as the 'principle of continuous access' that arises when learners re-establish their mistakes. The concept of Zone of Proximal Development (ZPD) views language acquisition as a shared process between the individual and other people through the basis of scaffolding. Thus, research on $\mathrm{CF}$ under the sociocultural paradigm seeks to answer how the implementation of corrective strategies to the learners' ZPD can assist learning (Aljaafreh \& Lantolf, 1994). Nonetheless, Carr and Weinmann (2018) suggest that the shift towards self-regulation within learners' ZPD through WCF is minimal. 
In the context of teacher feedback on assessment in relation to students' autonomy and self-regulation in learning, the aforementioned paradigms form the roots of social constructivism - a Vygotskian theory for learning in which "human development is socially situated and knowledge is constructed through interaction with others" (McKinley, 2015, p.1; Vygotsky, 1978). By interacting with the teacher and other students, new knowledge is created by integrating novel information into current existing knowledge; in this case, the students' existing schema or thought pattern for ESL writing. Students learn by sharing their experiences through discussions in order to solve real life adaptive problems. This is done by matching new ideas with current knowledge and adapting rules to make sense of the world, i.e., using teacher CF to improve their writing. The teacher, on the other hand, becomes a facilitator of learning by acknowledging students' pre-existing writing knowledge, guiding the writing activity to address their tacit knowledge, and further building on them. Hence, a collaborative problem-solving environment is created to encourage active learning among students (McLeod, 2019).

Other theories such as Ausubel's (1986) assimilation theory relates new concepts to the existing propositional framework that occurs from learners' interlanguage. It considers the provision of $\mathrm{CF}$ as an efficient method of expediting language comprehension. The interlanguage system is developed when learners receive error feedback and draw their attention towards its linguistic form (Eslami, 2014). Sweller's (1988) Cognitive load theory views the importance of creating a link between newly obtained information and the existing schematic structures in long-term memory to ensure that learners remember what they have learnt over a long period of time. An ideal learning setting is created by reducing the load on working memory, subsequently increasing the repeated rotation of long-term memory. Since WCF highlights the learner's weak areas and allows them to process linguistic content, it may benefit learners by adapting knowledge as a way of scaffolding to prompt them in long-term memorisation.

\section{Direct and Indirect Feedback}

Corrective feedback gives an implicit or explicit indication of wrong language use to the learner. The explicit form, Direct CF is when 
the teacher marks the error and provides the student with the correct form; the teacher provides feedback on the correct linguistic form or structure to the student above the linguistic error. This form of $\mathrm{CF}$ is particularly preferred by learners with low language proficiency as they find it difficult to correct their language errors. Nonetheless, scholars are of view that it discourages long-term learning due to the reduced cognitive processes on the learner's part (Bitchener \& Knoch, 2010; Ellis, 2009; Eslami, 2014; Ferris, 2003; Jamalinesari et al., 2015; Mollestam \& Hu, 2016). Direct CF involves inserting a phrase or morpheme, eliminating unnecessary words, providing the appropriate structure or word form, or even incorporating written and spoken metalinguistic explanation (Gholaminia, Gholaminia, \& Marzban, 2014).

The implicit form, Indirect $\mathrm{CF}$ is when the teacher indicates that the student has made an error, without providing the correct form or without providing correction, leaving it up to the student (Ellis, 2009). According to Bitchener and Knoch (2008) and Ferris (1995), the form of indirect CF may vary based on explicitness (e.g., coding or underlining errors). A further distinction is drawn for the use of code; coded feedback identifies the error and type involved whereas uncoded feedback underlines the error but leaves it to the student to determine the error (Jamalinesari et al., 2015). Coded feedback is advantageous as it enables students to treat error correction as an active process which may influence them in learning better (Westmacott, 2017). As such, learners are required to engage in guided learning and problem solving that allow reflection on linguistic forms and promote long-term acquisition (Lalande, 1982).

Scholars are divided as to whether the direct or indirect approach is better for WCF. Chandler (2003) believes the indirect approach might fail as learners will not have enough information to resolve complex errors, arguing that the direct method allows learners to internalise the appropriate forms supplemented by the teacher. It also offers learners explicit information, allowing them to test out their hypothesis (Bitchener \& Knoch, 2010). Direct CF is deemed appropriate for (1) beginner students, (2) situations when errors cannot be self-corrected, or (3) teachers who want to draw students' attention to other error patterns which require student correction. However, indirect corrective feedback can help learners improve accuracy in their writing as students who received feedback on 
their errors have been able to improve their skill by practising the structure (Hosseiny, 2014; Swain, 1985). This finding is supported by Eslami (2014) who found a strong connection between written corrective feedback and writing accuracy.

Although indirect corrective feedback can help learners improve accuracy in their writing, reducing confusion further and providing students with the information to solve complex errors with more immediate results may be more helpful. For this reason, direct CF might be more useful for learners at lower proficiency levels as they have fairly limited linguistic knowledge (Bakri, 2015; Bitchener, 2012). A study by Liu and Jhaveri (2019) determined how WCF can contribute to students' grammatical error corrections in their written work. It was found that direct $\mathrm{CF}$ was the most effective form of WCF in rectifying grammatical errors especially articles, tenses and prepositions. This finding is in tandem with Aseeri (2019) and Saeli (2019) who found that ESL teachers mostly practised direct feedback due to students' preference for it.

However, Ferris (2002) sees indirect CF as more impactful and suitable than direct $\mathrm{CF}$, stating that practitioners unintentionally use direct CF to change the learner's intended message because of misinterpretation. Indirect feedback gets the students to take part in the process of repair which allows for a proper framework to acknowledge solutions. On the other hand, students given direct CF have teachers providing the appropriate form, and thus do not take the initiative to make use of their own resources (Swain, 1985; Hosseiny, 2014). In fact, indirect feedback helps students to reinforce their form-focused knowledge and encourage further self-learning (Westmacott, 2017).

A study by Çepnia (2016) looked into indirect and direct CF from the sociocultural and cognitive-interactionist paradigms. The first strategy focussing on indirect feedback was to scaffold students to correct their own errors using methods that began from implicit to explicit assistance. According to Aljaafreh and Lantolf (1994), the sociocultural perspective regards error correction as a social activity that involves both the teacher and learner in meaningful transactions, with decreasing assistance over a period of time The results reflected this when the feedback applied in the indirect CF group reduced over time while direct CF group remained constant (Çepnia, 2016). 
Jamalinesari et al. (2015) compared the effects of the two forms of feedback on writing using eight grammatical errors. Students who received indirect feedback performed better than those given direct feedback, and improved their linguistic accuracy on the new writing task.

Daneshvar and Rahimi (2014) also found that indirect feedback had more effect than direct feedback, emphasizing the significant role of recast WCF in helping learners self-edit their own writing over time. It also encouraged students to take a more critical outlook at their own L2 writing and identify problems. Nonetheless, both experimental groups in the study had better pre-test, post-test and delayed post-test scores than the control group, and that their use of the target grammatical structures was retained in their writing in delayed post-tests. Eslami (2014) suggested a lasting effectiveness of indirect over direct feedback as learners who were given indirect CF performed significantly better than those with direct CF. In fact, indirect WCF might be a more superior form of error correction considering the factors of accuracy and time. Most teachers regard direct error coding to be slower as it takes time to spot errors and apply indirect methods when students possess sufficient linguistic knowledge to self-correct errors and self-edit text. Westmacott (2017) explored how students responded to various forms of feedback. It was found that the majority viewed indirect feedback as more useful than direct feedback, believing that indirect feedback prompted their "deeper cognitive processing and learning" (Westmacott, 2017, p. 17). This finding is in tandem with $\mathrm{Li}$ and $\mathrm{He}$ (2017) who found that most Chinese secondary students preferred indirect WCF, it being the most common form of WCF provided by their ESL teachers.

Past studies indicate some support for using indirect and direct feedback to expand learners' grammatical accuracy. For example, Hosseiny (2014) explored the relative effectiveness of two types of WCF in the context of L2 development. Learners who received WCF were found to have better grammar than those who did not receive it, although the feedback generated was considerably less than ideal. Likewise, a study by Babanoğlu, Ağçam and Badem (2018) showed that both direct and indirect WCF have similar influence on EFL learners' performance. Nonetheless, the type of feedback can be determined by its purpose; direct feedback can be more effective for revising purposes whereas indirect feedback can be more effective for learning purposes (Poorebrahim, 2017). 


\section{Focused and Unfocused Corrective Feedback}

According to Ellis (2009), focused CF targets only one or a few error types to be corrected but ignores other errors whereas unfocused CF targets many or all error types. The latter is normal practice in writing institutions where teachers correct all errors within the learners' written work, and is seen as extensive as it treats multiple errors (Bakri, 2015; Eslami, 2014).

Bitchener (2012) states that focused CF may be useful to students of lower proficiency levels as these students would be more likely to notice and understand corrections targeted at a few categories, while learners with higher proficiency levels would find unfocused $\mathrm{CF}$ more useful as it pivots on a larger range of linguistic concerns. In other words, low-achieving students would be given focused $\mathrm{CF}$ whereas high-achieving students would be provided with unfocused CF (Mollestam \& Hu, 2016). The focused approach looks into grammatical features which are rule-based (tenses and articles) rather than item-based (prepositions), which means that grammatical errors can be easily rectified (Ferris, 2002). In contrast, unfocused $\mathrm{CF}$ applies an unorganised approach to error correction. Although unfocused WCF can discourage learners from attempting complex writing features, it helps them acquire language and gain complexity in their interlanguage, which further improves their accuracy and lessens the number of errors being made in their writing (Ruegg, 2010; Fazilatfar, Fallah, Hamavandi, \& Rostamian, 2014). This explains the findings of Aseeri's (2019) study where both teachers and students at the university level preferred unfocused $\mathrm{CF}$ over focused CF.

Sheppard (1992) compared the effects of error coding (indirect CF) and holistic comments (unfocused CF) to determine the accurate use of punctuation, subordination and verb tenses among L2 learners. The group that received unfocused CF outperformed the group that received indirect $\mathrm{WCF}$ and even regressed over time, concluding that grammatical error correction had a negative effect on L2 students. Farrokhi (2012) found students who were given focused $\mathrm{CF}$ performed better than those given unfocused CF. Chandler (2003) found CF to be effective; students tend to write more when no $\mathrm{CF}$ was given to them, but what is more important is that they learn their L2 correctly or they would end up producing long but inaccurate texts. Studies have also shown that focused CF is more beneficial than unfocused $\mathrm{CF}$, particularly for $\mathrm{L} 2$ beginners, and that 
a mix of both forms of $\mathrm{CF}$ is better for students in the advanced level. However, a majority who depend on focused CF become demotivated and more anxious due to the introduction of unfocused CF (Bakri, 2015).

\section{Metalinguistic Corrective Feedback}

Ellis (2009) defines metalinguistic CF as providing learners with some form of explicit comments about the nature of the errors they have made, as they are coded, encoded or grammatically explained, most commonly through the use of error codes. According to Bitchener, Young and Cameron (2005), coded feedback points the exact location of the error and the type, whereas encoded feedback involves the teacher showing the approximate location of the error for students to identify and correct the mistake. The latter form of correction is also known as indirect metalinguistic feedback. Another form of correction is a brief grammatical explanation in which the teacher provides descriptions related to the error. Metalinguistic feedback can also be categorised as written and oral in form. Written feedback involves the teacher providing the explanation on the student's paper whereas oral feedback may be in the form of a short lecture to a big group of students (Bitchener et al., 2005, Bitchener, 2008). The provision of metalinguistic CF using another medium of instruction (typically the students' mother tongue) can also enhance communication by making it easier for teachers to highlight and explain error corrections to low-proficiency students (Aseeri, 2019).

Metalinguistic information helps learners generalize form into new contexts (Sauro, 2009). Carroll (2001) explored ESL participants' use of nouns from verb stems. The results showed that groups that were given direct or indirect metalinguistic feedback on their errors performed significantly better than the control group under new contexts. Sheen (2007) compared direct error correction with metalinguistic $\mathrm{CF}$ and found that those who received direct metalinguistic $\mathrm{CF}$ had better delayed post-test results. Bitchener (2008) examined the effect of metalinguistic CF on improving the accuracy of ESL learners' use of definite and indefinite articles. Respondents who received both oral and written metalinguistic $\mathrm{CF}$ together with direct error correction as well as those who only received direct $\mathrm{CF}$ outperformed the control group. This meant that oral metalinguistic feedback did not make a difference when combined with written metalinguistic feedback. However, in a 
counter-study, Rezazadeh, Ashrafi and Foozunfar (2018) found that a combination of both oral and written feedback enhanced students' written accuracy more than merely oral or written feedback alone. Nonetheless, students reacted positively towards all forms of feedback.

Sauro (2009) explored metalinguistic information about the nature of errors by using computer-delivered pre-tests, post-tests and delayed post-tests of knowledge (acceptability judgments) to measure learning outcomes. It was concluded that the metalinguistic group that was exposed to the type of corrective feedback from familiar contexts had immediate gains that alerted learners to their errors when developing short-term knowledge on L2 grammar. A study by Tanveer, Malghani, Khosa and Khosa (2018) also found that students who received direct and indirect metalinguistic CF were able to revise and create new drafts with less errors.

\section{Electronic Corrective Feedback}

With technology becoming a more inclusive occurrence in education and preferred by students and teachers for L2 writing (Hyland, 2010), an increasing number of teachers require students to submit their work online and provide electronic feedback (e-feedback) either through chat rooms, forums or by using word-processing software online. The teacher might indicate the error by providing a hyperlink to a concordance file that provides correct usage (Bakri, 2015). The provision of electronic $\mathrm{CF}$ can lead to better writing products, writing and working on large chunks of information, and macrorevision (Sullivan \& Pratt, 1996; Tuzi, 2004). The introduction of new technologies in the classroom can also motivate students to learn more (Bellés-Calvera \& Bellés-Fortuño, 2018).

Ware and Warschauer (2006) are of the view that direct human feedback can be potentially replaced or enhanced due to the versatility of software-generated feedback. In the context of ESL writing, they conducted evaluative studies that compared the effects of traditional face-to-face feedback with the more sophisticated computer-mediated human feedback. Tafazoli, Nostatzadeh and Hosseini (2014) investigated the effectiveness of feedback on the grammatical accuracy of English for Specific Purposes (ESP) students' writing, focusing on comparing teacher impact in print and electronic mode. It was found that online mode students made specific, local changes and that more revisions were made through online feedback as opposed to the conventional print form. 
On average, WCF is seen as somewhat effective in helping students improve linguistic accuracy as it is not a holistic solution for improving error correction. However, the responses are placed on the positive side of the scale, which indicates that although WCF has potential, it is still ineffective among students who are not motivated to take advantage of the feedback provided (Evans, Hartshorn, \& Tuioti, 2010). According to Bakri (2015), the findings are inconclusive as one type of learner may find a certain type of error correction more beneficial than the other. For example, direct metalinguistic feedback benefits learners with high aptitude and analytically strong language learners as they are better engaged with cognitive comparison. In conclusion, learners would benefit from different types of $\mathrm{CF}$, depending on their high or low working capacities.

\section{What do Teachers Expect Students to do with Feedback?}

Mollestam and $\mathrm{Hu}$ (2016) interviewed teachers and found that they preferred to provide their L2 students with written CF as it saves a lot of time. Most of them gave direct written $\mathrm{CF}$ to students aged 10 to 11 , while older students were given indirect written CF. Their belief was that older students should be able to identify errors for themselves as long as they are proficient in their L2, whereas young children would have to be corrected on their form.

Although underlining errors is sufficient for students to self-correct (Chandler, 2003), direct CF has proven to be most effective and appreciated by students, who find it easy both to understand and correct. Karim (2013) found that for most teachers, an immediate connection to the correct form is important in relating the correction for students to internalize it better. Evans, Hartshorn and Tuioti (2010) found three main reasons for providing WCF: 1) students need help correcting their mistakes through awareness, 2) students expect to be corrected as it is believed to be part of the teaching process, and 3) students need to be corrected for guidance and learning how to write correctly. To elaborate, the main purpose of CF is to help students be aware of language, build self-edit skills and understand errors. Such feedback is to help students notice the gap between their errors and the correction applied. Students expect to be corrected on grammar errors and raise consciousness on their error patterns. By understanding errors, they can improve the foundation for their writing and produce quality work. Besides focusing on organization and content, language form is equally important in the context of 
writing. Introducing CF in ESL instruction helps reinforce what has been learnt in class, motivates students to do better, corrects errors in speaking, provides a record in error patterns and is part of the learning process.

A study by Gholaminia et al. (2014) focussing on metalinguistic feedback among Iranian EFL learners concluded that teachers want learners to utilise writing activities more productively. The use of metalinguistic codes for error correction enables learners to restructure their drafts repeatedly, emphasise on paragraph quality, be more attentive to their own errors and corrections, and accelerate their writing progression. Learners in anticipation of writing assessments will be more motivated and take responsibility over their learning. The study found that error feedback improved learners' writing ability, accuracy and awareness of errors, ultimately decreasing errors as they monitor themselves to be independent learners.

As noted by Ferris, Liu and Rabie (2011), teachers within their study wanted their students to improve and reach their fullest potential by using the provided CF. A majority of the teachers believed that students needed CF, and that WCF was an effective pedagogical practice. Saeli (2019) found that teachers provided teachergenerated grammar feedback and comprehensive correction based on their students' preferences and positive perceptions. $\mathrm{Li}$ and $\mathrm{He}$ (2017) reported no significance differences between teachers' WCF provision and students' preferences. However, Mao and Crosthwaite (2019) found that although teachers were of view that they provided direct feedback, the reality was that they provided indirect feedback in practice.

\section{Past Studies on Written Corrective Feedback}

Teachers and students alike believe that feedback plays an important part in the writing process, especially so for L2 writing where the main goal is to teach the writing conventions and culture of the target language, and its grammatical forms (Hedgcock \& Lefkowitz, 1994; Paulus, 1999).Although some teachers take their students' perception of WCF into consideration, most are fully aware of the type of WCF addressing local (e.g., grammar, spelling, punctuation) and global issues (e.g., content, organisation, ideas), paying more attention to local issues (Mao \& Crosthwaite, 2019). They also adhere to their beliefs about written feedback (Ferris, 2006; Reid, 1993). 
According to Faqeih (2015), sensitivity to error correction (regardless of the learner's or teacher's) is an important factor in determining the most impactful kind of WCF. The results emphasise the necessity for varied WCF forms to meet various needs of learners. Specifically, the direct approach is preferred by both teachers and students (Ferris \& Roberts, 2001), but a greater cognitive effort is expanded on the students' part when indirect feedback is required to make corrections. More time is spent on fine-tuning if the hypothesized corrections are correct (Chandler, 2003).

Amrhein and Nassaji (2010) found similarities and differences in perceptions of WCF among students and teachers. Although both teachers and students viewed the provision of WCF as important, their response differed with regards to the amount of errors to be marked. Students believed all errors should be marked, disagreeing with teachers who only responded to errors that interfered with communication, content or ideas. Students believed that by seeing all their errors marked, WCF would help them learn from errors and remember corrections better. In contrast, teachers tended to differentiate between errors they believed were more or less important, being selective in attending to communication or accuracy. Both teachers and students in the study saw WCF as a learning tool for consistently marking errors as it allowed both groups to identify and remember error patterns. This does not align with earlier findings (Ferris \& Roberts, 2001; Hendrickson, 1980; Makino, 1993) which suggest that if teachers mark every error, it leaves little room for self-correction on the student's part. On the other hand, students also believe it is the responsibility of the teacher to have their errors explicitly marked and corrected, which allows them insight to fix mistakes. This will in turn allow them to perfect their English and to be error-free. Although learners tend to ask for more explicit WCF, teachers who prefer to give less explicit WCF are of view that it encourages autonomous learning since it encourages more effort from students (Amrhein \& Nassaji, 2010). From the teachers' perspective, their WCF preferences could also be influenced by their workload, burnout levels and self-efficacy levels (Köksal, Özdemir, Tercan, Gün, \& Bilgin, 2018).

In the Malaysian ESL classroom, teachers' WCF has been found to help university students to address grammatical errors and language problems in order to write better and more accurately (Rahim, Jaganathan, \& Mahadi, 2019), However, there is a gap in the literature on the provision of WCF in Malaysian secondary schools, 
which this study aims to fulfil. Teachers are encouraged to take their students' preference and attitudes into account when choosing the appropriate type of WCF, since learners have differing needs in acquiring accurate writing skills. The ESL writing classroom should incorporate both form and meaning into written tasks. Considering that suitable provision of WCF is dynamic and context-based, pedagogical education, personal experience and context of teaching are prime examples of the many variables that need to be accounted for (Bal-Gezegin, 2015; Faqeih, 2015).

\section{METHODOLOGY}

This is a quantitative study that used a survey questionnaire adapted from Bitchener and Knoch (2010) to collect data from students. The questionnaire content was validated by two lecturers. This was followed by a pilot test on 68 Form 4 students in a secondary school. The internal consistency of the questionnaire was reported at 0.82 by using Cronbach's alpha, which indicated an acceptable internal consistency.

The data were collected from 720 Form Four students from ten different schools in Penang, Malaysia. The respondents were taking the 1119 English Language subject, and had similar characteristics with regards to their age (16 years old) and educational background. Form Four students were chosen as they had received the most years of English language education, with the exception of Form Five students, who were not chosen as they were preparing for their national Malaysian Certificate of Education examination. Students were chosen using systematic sampling by dividing the total class size until the desired sample of 100 students per school was reached. Although the ideal sample size was 1000 , a $72.0 \%$ response rate yielded 720 student participants.

The instrument used in this study was a questionnaire with a 4-point Likert scale (1: 'Strongly Agree'; 2: 'Agree'; 3: 'Disagree' and 4: 'Strongly Disagree'). The research procedure consisted of 1) briefing the participants, 2) gaining their ethical consent, 3) distributing the questionnaire, 4) collecting the questionnaire, and 5) analysing the data. The data obtained through the questionnaire were tabulated and analysed using the Statistical Program for Social Sciences (SPSS Version 23). The statistical method used was descriptive statistics in which data were represented through items, frequency, percentage, 
mean, and standard deviation. The findings were then used to address and discuss the research objectives.

\section{RESULTS}

Table 1 shows the different types of errors students believed their English teacher should mark. $86.5 \%$ agreed that teachers should mark all errors. The majority of students (76.2\%) disagreed on teachers only marking all major errors and marking no errors. On a similar note, students disagreed when teachers mark most errors (69.8\%) and mark specific errors (66.7\%). Lastly, 55.6\% of the students disagreed on their teacher's habit of marking only errors.

Table 1

The Different Types of Errors Marked by English Teachers in Writing

\begin{tabular}{lll}
\hline & $\begin{array}{c}\text { YES } \\
(\%)\end{array}$ & $\begin{array}{l}\text { NO } \\
(\%)\end{array}$ \\
\hline Mark All Errors & 86.5 & 13.5 \\
Mark All Major Errors & 23.8 & 76.2 \\
Mark Most Errors & 30.2 & 69.8 \\
Mark Specific Errors & 33.3 & 66.7 \\
Mark Only Errors & 44.4 & 55.6 \\
No Mark & 23.8 & 76.2 \\
\hline
\end{tabular}

Table 2 shows the types of WCF provided by teachers to their students. There were many forms of written corrections students received from their teachers where students strongly agreed. The two most popular were intro and thesis, with $59.8 \%$ and $58.4 \%$ agreement respectively. A majority of corrections fell under grammar, being the next struggle for students, such as accurate spelling (57.6\%), sentences made must have a clear meaning (54.4\%), and punctuation (52.0\%). Teachers also focused on content and ideas with the student, albeit on a smaller scale, with quality writing $(50.4 \%)$, understanding of the text written (49.6\%), both appropriate words and facts (48.8\%), and finally conclusion (47.2\%). Most students agreed that teachers also focused on the flow of content within the writing style, such as 
transition of ideas (60.0\%) and smooth layout of paragraphs (51.2\%), followed by both avoiding stray ideas and comprehension (49.6\%). However, a majority of students disagreed on previous (24.8\%), that is, teachers usually did not relate correction built up on the previous sentence $(\mathrm{M}=2.01)$. Similarly, the beginning of sentences must vary $(22.4 \%)$ was rated as the second highest $(\mathrm{M}=1.96)$, and finally sentences being conversational $(20.0 \% ; \mathrm{M}=1.98)$.

Table 2

Types of Written Corrective Feedback (WCF) Provided by Teachers to Their Students in English Language Writing Classes

\begin{tabular}{lccccc}
\hline & 1 & 2 & 3 & 4 & Mean $(\mathrm{M})$ \\
& $(\%)$ & $(\%)$ & $(\%)$ & $(\%)$ & \\
\hline Thesis & 58.4 & 40.0 & 1.6 & 0.0 & 1.43 \\
Topic Sentence & 27.2 & 51.2 & 20.0 & 1.6 & 1.96 \\
Transition & 32.8 & 60.0 & 5.6 & 1.6 & 1.76 \\
Logical & 44.8 & 44.8 & 9.6 & 0.8 & 1.66 \\
Topic & 42.4 & 41.6 & 14.4 & 1.6 & 1.75 \\
Quality Writing & 50.4 & 33.6 & 14.4 & 1.6 & 1.67 \\
Related Ideas & 42.4 & 43.2 & 13.6 & 0.8 & 1.73 \\
Avoid Stray & 27.2 & 49.6 & 19.2 & 4.0 & 2.00 \\
Facts & 48.8 & 47.2 & 4.0 & 0.0 & 1.55 \\
Beginning Vary & 29.6 & 46.4 & 22.4 & 1.6 & 1.96 \\
Conversational & 24.0 & 44.2 & 20.0 & 0.8 & 1.98 \\
Previous & 28.8 & 44.0 & 24.8 & 2.4 & 2.01 \\
Comprehensible & 43.2 & 49.6 & 7.2 & 0.0 & 1.64 \\
Clear Meaning & 54.4 & 34.4 & 11.2 & 0.0 & 1.57 \\
Flow & 44.0 & 46.4 & 9.6 & 0.0 & 1.66 \\
Smooth & 42.4 & 51.2 & 6.4 & 0.0 & 1.64 \\
Accurate Sound & 38.4 & 45.6 & 12.0 & 4.0 & 1.82 \\
Unfamiliar Term & 34.4 & 41.6 & 16.8 & 7.2 & 1.97 \\
Conclusion & 47.2 & 47.2 & 5.6 & 0.0 & 1.58 \\
Punctuation & 52.0 & 38.4 & 7.2 & 2.4 & 1.60 \\
Appropriate Words & 48.8 & 40.0 & 8.0 & 3.2 & 1.66 \\
Understanding & 49.6 & 44.0 & 4.0 & 2.4 & 1.59 \\
Accurate Spelling & 57.6 & 36.8 & 4.0 & 1.6 & 1.50 \\
Intro & 59.2 & 38.4 & 2.4 & 0.0 & 1.43 \\
\hline & & & & & \\
\hline
\end{tabular}

Scale: 1-Strongly Agree 2-Agree 3-Disagree 4-Strongly Disagree 
Table 3 shows teachers' expectations of students towards their WCF. Students strongly agreed that teacher feedback improves writing (61.6\%), in which direct feedback has helped improve writing. They also strongly agreed that teachers locate and correct errors (57.6\%). $52.8 \%$ agreed that students know how to do corrections from the feedback provided. Less students (21.6\%) strongly agreed that they locate and correct own errors. Nonetheless, $40.0 \%$ still agreed, resulting in a mean of 2.30. Overall, the results show a varied outlook on how some students can self-manage own errors while others are not able to do so, with a huge preference for teacher correction.

Table 3

Teachers' Expectations of Students towards their WCF

\begin{tabular}{lccccc}
\hline & $\begin{array}{c}1 \\
(\%)\end{array}$ & $\begin{array}{c}2 \\
(\%)\end{array}$ & $\begin{array}{c}3 \\
(\%)\end{array}$ & $\begin{array}{c}4 \\
(\%)\end{array}$ & Mean (M) \\
\hline $\begin{array}{l}\text { Students know how to do } \\
\text { corrections }\end{array}$ & 20.8 & 52.8 & 21.6 & 4.8 & 2.10 \\
$\begin{array}{l}\text { Teachers locate and correct } \\
\text { errors }\end{array}$ & 57.6 & 34.4 & 5.6 & 2.4 & 1.53 \\
$\begin{array}{l}\text { Students locate and correct } \\
\text { own errors }\end{array}$ & 21.6 & 40.0 & 24.8 & 13.6 & 2.30 \\
$\begin{array}{l}\text { Teachers feedback } \\
\text { improve student writing }\end{array}$ & 61.6 & 34.4 & 3.2 & 0.8 & 1.43 \\
\hline
\end{tabular}

Scale: 1-Strongly Agree 2-Agree 3-Disagree 4-Strongly Disagree

Table 4 shows the reactions of students towards WCF. Many students strongly agreed that students make progress in writing (38.4\%), followed by after marking the teacher holds discussion (29.6\%). Most students agreed that after marking, the teacher ensures errors are corrected (51.2\%), followed by teachers use code to mark writing (46.4\%), and the student prefers code used in marking (46.4\%), which relates to the issue of students better identifying error corrections. $34.4 \%$ of students disagreed that the teacher does not do anything, which is not common practice for teachers to not present any feedback to the learners. This item also had the highest strong disagreement (17.6\%), resulting in a mean of 2.46. Students also disagreed to corrections recorded in notebook 
(32.0\%) and student understands code and symbol used (32.8\%), where the teacher's assistance is still required to identify errors and the form of corrections to be done.

Table 4

Students' Reactions towards WCF

\begin{tabular}{lccccc}
\hline & $\begin{array}{c}1 \\
(\%)\end{array}$ & $\begin{array}{c}2 \\
(\%)\end{array}$ & $\begin{array}{c}3 \\
(\%)\end{array}$ & $\begin{array}{c}4 \\
(\%)\end{array}$ & Mean (M) \\
\hline $\begin{array}{l}\text { After marking teacher } \\
\text { does not do anything }\end{array}$ & 23.2 & 24.8 & 34.4 & 17.6 & 2.46 \\
$\begin{array}{l}\text { After marking teacher } \\
\text { holds discussion }\end{array}$ & 29.6 & 44.8 & 17.6 & 8.0 & 2.04 \\
$\begin{array}{l}\text { After marking teacher } \\
\text { ensures errors corrected }\end{array}$ & 28.0 & 51.2 & 16.0 & 4.8 & 1.98 \\
$\begin{array}{l}\text { After marking corrections } \\
\text { recorded in notebook }\end{array}$ & 16.8 & 40.0 & 32.0 & 11.2 & 2.38 \\
$\begin{array}{l}\text { After marking teacher } \\
\text { discuss error in classroom }\end{array}$ & 31.2 & 38.4 & 22.4 & 8.0 & 2.07 \\
$\begin{array}{l}\text { Teacher uses codes to } \\
\text { mark writing }\end{array}$ & 20.0 & 46.4 & 23.2 & 10.4 & 2.24 \\
$\begin{array}{l}\text { Student understands code } \\
\text { and symbol used }\end{array}$ & 16.0 & 39.2 & 32.8 & 12.0 & 2.41 \\
$\begin{array}{l}\text { Student prefers code used } \\
\text { in marking }\end{array}$ & 15.2 & 46.4 & 22.4 & 16.0 & 2.39 \\
$\begin{array}{l}\text { Student makes progress in } \\
\text { writing }\end{array}$ & 38.4 & 50.4 & 6.4 & 4.8 & 1.78 \\
\hline
\end{tabular}

Scale: 1-Strongly Agree 2-Agree 3-Disagree 4-Strongly Disagree

Table 5 shows the perceptions of students towards the effectiveness and usefulness of WCF. A majority of students preferred feedback on content (64.8\%), grammar $(61.1 \%)$, vocabulary $(59.2 \%)$, and feedback on all errors (52.8\%). This is already an indicator of specific ways they believe WCF should function and help in their writing, particularly with regards to the notion of teachers providing direct assistance. This relates with students' strong agreement towards teachers providing feedback on grammar and vocabulary of writing $(57.6 \%)$ and on content and organisation in writing (52.8\%), whereby there is a need for explicit feedback for not only what is preferred but also for what should take place in learning. 
Table 5

Perceptions of Students towards the Effectiveness and Usefulness of WCF

\begin{tabular}{|c|c|c|c|c|c|}
\hline Student and Teacher Perception & $\begin{array}{c}1 \\
(\%)\end{array}$ & $\begin{array}{c}2 \\
(\%)\end{array}$ & $\begin{array}{c}3 \\
(\%)\end{array}$ & $\begin{array}{c}4 \\
(\%)\end{array}$ & Mean $(\mathrm{M})$ \\
\hline Provide feedback on grammar & 61.1 & 37.6 & 0.8 & 0.0 & 1.39 \\
\hline Provide feedback on vocabulary & 59.2 & 36.8 & 4.0 & 0.0 & 1.46 \\
\hline Provide feedback on content & 64.8 & 28.8 & 6.4 & 0.0 & 1.42 \\
\hline Provide feedback on organisation & 50.4 & 42.4 & 5.6 & 1.6 & 1.58 \\
\hline Provide feedback on all errors & 52.8 & 41.6 & 4.8 & 0.8 & 1.54 \\
\hline $\begin{array}{l}\text { Important teacher feedback on } \\
\text { errors }\end{array}$ & 49.6 & 42.4 & 7.2 & 0.8 & 1.59 \\
\hline $\begin{array}{l}\text { Teachers provide feedback on } \\
\text { errors in writing }\end{array}$ & 46.4 & 40.0 & 11.2 & 2.4 & 1.70 \\
\hline $\begin{array}{l}\text { Teachers give various writing } \\
\text { assignments }\end{array}$ & 34.7 & 46.8 & 12.1 & 6.5 & 1.90 \\
\hline $\begin{array}{l}\text { Teachers frequently give written } \\
\text { assignments }\end{array}$ & 35.2 & 42.4 & 20.8 & 1.6 & 1.89 \\
\hline $\begin{array}{l}\text { Teachers correct all errors in } \\
\text { writing }\end{array}$ & 41.6 & 44.0 & 13.6 & 0.8 & 1.74 \\
\hline $\begin{array}{l}\text { Teachers provide feedback on } \\
\text { grammar and vocabulary of } \\
\text { writing }\end{array}$ & 57.6 & 37.6 & 4.8 & 0.0 & 1.46 \\
\hline $\begin{array}{l}\text { Teachers provide feedback on } \\
\text { content and organisation in } \\
\text { writing }\end{array}$ & 52.8 & 42.4 & 4.0 & 0.8 & 1.53 \\
\hline
\end{tabular}

Scale: 1-Strongly Agree 2-Agree 3-Disagree 4-Strongly Disagree

Students agreed that teachers should give various writing assignments $(46.8 \%)$, with only $12.1 \%$ who disagreed and $6.5 \%$ who strongly disagreed, resulting in the highest mean of 1.90. This data shows that although it was somehow practised, providing various material to students might not be a common occurrence. For the notion that teachers frequently give written assignments, $20.8 \%$ of students disagreed while the majority $(42.4 \%)$ agreed that they were given materials to work with, resulting in a mean of 1.89 . The fact that $44.0 \%$ of the students agreed that teachers correct all errors in writing displayed their preference for direct feedback on writing. 


\section{DISCUSSION}

The first research objective was to determine the types of WCF provided to secondary students in the Malaysian ESL classroom. The results showed that most learners preferred and benefited from direct feedback, and tended to focus on form such as grammar, organisation of paragraph writing, content and clarity of ideas. Teachers were actively using WCF in their teaching rather than not presenting feedback at all. Although various forms of feedback are presented within the English language classroom for the purpose of improvement and ensuring learners understand their errors, the data from this study suggest that direct feedback is used over any other form by teachers and students. This finding is in tandem with Liu and Jhaveri (2019), Aseeri (2019) and Saeli (2019) who also found that direct CF was the most preferred and practiced form of WCF. The teachers adopted a social constructive perspective towards providing suitable feedback based on students' needs and preferences, which was direct $\mathrm{CF}$.

It was found that students wanted teachers to mark all errors (86.5\%) while disagreeing with the marking of all major errors (76.2\%). This indicates that students believe feedback on all errors is vital to their understanding, and helps them learn and remember the material better than if specific errors are discriminated against or no feedback is given at all (Chandler, 2003). Eslami (2014) pointed out that students attempted to correct their linguistic errors through their teacher's marking, believing that it would hasten their assimilation process and further develop their interlanguage system if all available errors were identified and corrected. It seems that direct CF is preferred by teachers and students alike as both are able to form immediate corrections and internalize them easier. This was also seen in Van Beuningen, de Jong and Kuiken's (2008) study where two direct and indirect $\mathrm{CF}$ groups were compared to two control groups with similar assignments. Although both $\mathrm{CF}$ groups showed significant accuracy gains, direct $\mathrm{CF}$ was found to have long-term effects on accuracy. This improvement in accuracy is further supported by past studies (Bitchener \& Knoch, 2008, 2010; Bitchener et al., 2005).

Teachers tended to provide WCF in correcting technical errors such as Intro (59.8\%), Thesis (58.4\%), Accurate Spelling (57.6\%), Clear Meaning (54.4\%), and Punctuation (52.0\%). All these aspects focus 
on grammar, content, ideas and organisation in writing sentences. Teachers use WCF to help students learn from their errors, focussing on their weak areas. This in turn allows students to use the acquired new data to update their schematic structures, resulting in sustained learning (Sweller, 1998). However, Conversational (24.4\%) and Previous sentences (28.8\%) were not stressed as much as they were not seen as important or were too time-consuming. The lack of correction here reflects the increased workload for teachers if they continue marking every relation to previous sentences, or every mistake made, which can further affect their future WCF performance due to burnout (Köksal et al., 2018). In contrast, teachers were found to mark errors they believed were useful to language learning, specifically form-focused feedback, as language accuracy was important. This finding is supported by past studies (Amrhein \& Nassaji, 2010; Furneaux, Paran, \& Fairfax, 2007; Hyland, 2003; Lee, 2008; Rahim et al., 2019; Tanveer et al., 2018).

The second research objective was to examine students' responses and perceptions towards the provision of WCF. Students preferred direct feedback as it enabled them to understand errors clearly, but most were unable to self-regulate their own errors, with a majority unable to locate their own errors and becoming passive learners within the Malaysian schooling system. Data on the expectations of students regarding their WCF showed that students improved their writing skills based on the given feedback, albeit under the direct supervision of teachers, since $57.6 \%$ of students agreed that teachers should locate and correct their errors. Although students were comfortable with explicit, direct and explanatory feedback, some were unable to correct and locate their own errors (21.6\%); nor could they do their own corrections (20.8\%). This suggests that indirect feedback is not employed at all and that student autonomy is not present, hence their diminishing competence and ability to self-manage which ultimately leads to students preferring direct feedback. This finding is evident as teacher feedback only helped $38.4 \%$ of the students in the study to make progress in writing. The reality is that most students do not understand the use of code or symbols used by teachers when marking, and that teachers do not stress on recording corrections in notebooks.

The phenomenon of students' preference for the teacher's direct $\mathrm{CF}$, and for explicit and explanatory corrections would make them 
passive learners, relying on the given direction to improve rather than actively mastering the structure or material on their own (Ferris \& Roberts, 2001; Hendrickson, 1980; Makino, 1993). This is because the teacher gives students information on how to correct their errors, but does not prompt them on why the errors need to be corrected. As a result, students take the feedback for granted, resulting in a onesided learning environment where the teacher merely instructs. It also discourages students from playing an active role in improving their writing. Although WCF helps learners write better by bringing attention to their existing errors, it is unable to establish the type of errors as well as to what extent those errors counted. In addition, the use of WCF itself is not enough to correct all their errors (Clark \& Ouellette, 2008). Regarding error corrections, the students in this study primarily focused on grammar $(61.1 \%)$, vocabulary $(59.2 \%)$, content $(64.8 \%)$ and feedback on all errors (52.8\%). Students generally have a positive impression on form-focused errors in WCF; they are more concerned with error-free writing rather than conveying interesting and coherent ideas which deviated from their goals (Hedgcock \& Leftkowitz, 1994; Leki, 1991; Raimes, 1991).

\section{CONCLUSION}

The key findings highlight that many Malaysian English teachers provide students with direct feedback in error correction as it is found to be easy to understand, correct and has more clarity on the type of error made (Chandler, 2003). Although this form of WCF is expected to be part of the syllabus and implemented in the Malaysian ESL classroom, it elicits students' passive learning - they become too reliant on teachers for improvement and find it hard to progress and correct their own errors.

Nonetheless, what is more important is what the students want and need, since the effectiveness of WCF is dependent on students' preference (Li \& He, 2017; McCargar, 1993; Saeli, 2019; Schulz, 2001). In this case, direct feedback is more useful and therefore, has a positive impact on their writing. As a result of not incorporating student autonomy into WCF, such as focusing more on content and communication, students are not able to self-regulate those errors and be more creative with their writing, and may even result in lowering their language proficiency. Although indirect or unfocused feedback 
is typically more useful for advanced students, its implementation in the Malaysian context is doubtful as the education system puts students of various proficiency levels under the same umbrella; certain students will become more complacent as they hit a certain progression point.

Therefore, it is recommended that teachers become more aware of their learners' needs and the different types of WCF that can be provided to accommodate the varied levels of proficiency among their students. This is to ensure that they become active learners and to instil motivation for improving themselves under appropriate supervision. The study is significant to Malaysian secondary schools on its effects by depicting the many available forms of WCF in the ESL context that can be employed in schools besides the popularised Direct Feedback based on the syllabus. This study also recommends further research on Electronic $\mathrm{CF}$ in relation to the emerging trend of blended learning and the 21 st century classroom.

\section{ACKNOWLEDGEMENT}

This work was supported by a short-term grant (Grant No. 6315015) from Universiti Sains Malaysia.

\section{REFERENCES}

Aljaafreh,A., \& Lantolf, J.P. (1994). Negative feedback as regulation and second language learning in the zone of proximal development. Modern Language Journal, 78, 465-483. Retrieved from http://onlinelibrary.wiley.com/doi/10.1111/ j.1540-4781.1994.tb02064.x/pdf

Amrhein, H. R., \& Nassaji, H. (2010). Written corrective feedback: What do students and teachers think is right and why? Canadian Journal of Applied Linguistics/Revue canadienne de linguistique appliquee, 13(2), 95-127.

Aseeri, F. M. M. (2019). Written corrective feedback as practiced by instructors of writing in English at Najran University. Journal of Education and Learning, 8(3), 112-121.

Ausubel, D. P. (1986). Educational psychology: A cognitive view. New York: Holt, Rinehart and Winston. 
Babanoğlu, M. P., A ğçam, R., \& Badem, N. (2018). Explicit and implicit written corrective feedback in higher EFL education: Evidence from Turkey. Inonu University Journal of the Faculty of Education, 19(3), 104-116.

Bakri, H. (2015). The role of individual differences in second language writing corrective feedback. Arab World English Journal, 6(4).

Bal-Gezegin, B. (2015). Feedback in L2 writing: Voices from native and non-native English speaking teachers. Procedia - Social and Behavioural Sciences, 199, 763-769.

Bellés-Calvera, L., \& Bellés-Fortuño, B. (2018). Written corrective feedback with online tools in the Medicine classroom: Bombay TV. In López-García \& Manso (Eds.), Transforming education for a changing world (pp. 106-119). Netherlands: Adaya Press.

Bellon, J., Bellon, E. C., \& Blank, M. A. (1992). Teaching from a research knowledge base. New York: Macmillan.

Bitchener, J. (2008). Evidence in support of written corrective feedback. Journal of Second Language Writing, 17, 102-118.

Bitchener, J. (2012). A reflection on 'the language learning potential' of written CF. Journal of Second Language Writing, 21(4), 348-363.

Bitchener, J., \& Knoch, U. (2008). The value of written corrective feedback for migrant and international students. Language Teaching Research Journal, 12, 409-431.

Bitchener, J., \& Knoch, U. (2010). Raising the linguistic accuracy level of advanced L2 writers with written corrective feedback. Journal of Second Language Writing, 19, 207-217.

Bitchener, J., Young, S., \& Cameron, D. (2005). The effective of different types of corrective feedback on ESL student writing. Journal of Second Language Writing, 14, 191-205.

Carr, N., \& Weinmann, M. (2018). Written corrective feedback: The need for collaboration and multidirectional interaction. TESOL in Context, 27(1), 1-22.

Carroll, S. (2001). Input and evidence: The raw material of second language acquisition. Amsterdam: John Benjamins.

Çepnia, S. B. (2016). A replication study: Oral corrective feedback on L2 writing: two approaches compared. Procedia - Social and Behavioural Sciences, 232, 520-528.

Chandler, J. (2003). The efficacy of various kinds of error feedback for improvement in the accuracy and fluency of L2 student writing. Journal of Second Language Writing, 12, 267-296. 
Clark, H., \& Ouellette, M. (2008). Students' noticing and incorporation of written feedback: A snapshot of ESOL writing instructors' commentary on adult ESOL students' essays (Unpublished master's thesis). University of Texas, USA. Retrieved from http://hdl.handle.net/10106/669

Daneshvar, E., \& Rahimi, A. (2014). Written corrective feedback and teaching grammar. Procedia - Social and Behavioural Sciences, 136, 217-221.

Dlaska, A., \& Krekeler, C. (2013). The short-term effects of individual corrective feedback on L2 pronunciation. System, 41, 25-37.

Doughty, C. J. (2003). Instructed SLA: Constraints, compensation, and enhancement. In C. J. Doughty, \& M. H. Long (Eds.), The Handbook of Second Language Acquisition (pp. 256310). Malden, MA: Blackwell Publishing Ltd. http://dx.doi. org/10.1002/9780470756492.ch10

Ellis, R., Basturkmen, H., \& Loewen, S. (2002). Doing focus-onform. System, 30(4), 419-432. https://doi.org/10.1016/j. sbspro.2013.01.186

Ellis, R. (2009). A typology of written corrective feedback types. ELT Journal, 63(2), 97-107.

Ellis, R., \& Shintan, N. (2014). Exploring language pedagogy through second language acquisition research. New York: Routledge.

Eslami, E. (2014). The effects of direct and indirect corrective feedback techniques on EFL students' writing. Procedia Social and Behavioural Sciences, 98, 445-452.

Evans,N.W.,Hartshorn,K.J.,\&Tuioti,E.A.(2010).Writtencorrective feedback: The practitioners' perspective. International Journal of English Studies, 10(2), 47-77.

Evans, N. W., Hartshorn, K. J., McCollum, R. M., \& Wolfersberger, M. (2010). Contextualizing corrective feedback in L2 writing pedagogy. Language Teaching Research, 14, 445-463

Faqeih, H. I. (2015). Learners' attitudes towards corrective feedback. Procedia - Social and Behavioural Sciences, 192, 664-671.

Farrokhi, F. (2012). The effects of direct written corrective feedback on improvement of grammatical accuracy of high-proficient L2 learners. World Journal of Education, 2(2), 49-57.

Fathman, A., \& Whalley, E. (1990). Teacher response to student writing: Focus on form versus content. In B. Kroll (Ed.), Second language writing: Research insights for the classroom (pp.178-190). Cambridge: Cambridge University Press. 
Fazilatfar, A. M., Fallah, N., Hamavandi, M., \& Rostamian, M. (2014). The effect of unfocused written corrective feedback on syntactic and lexical complexity of L2 writing. Procedia Social and Behavioural Sciences, 98, 482-488.

Ferris, D. R. (1995). Teaching ESL composition students to become independent self-editors. TESOL Journal, 4(4), 18-22.

Ferris, D. R. (2002). Treatment of error in second language student writing. Ann Arbor, MI: The University of Michigan Press.

Ferris, D. R. (2003). Response to student writing: Implications for second language students. New Jersey: Lawrence Erlbaum Associates.

Ferris, D. R. (2006). Does error feedback help student writers? New evidence on the short- and long-term effects of written error correction. In K. Hyland \& F. Hyland (Eds.), Feedback in second language writing: Contexts and issues (pp. 81-104). London: Cambridge University Press.

Ferris, D. R., \& Roberts, B. (2001). Error feedback in L2 writing classes. How explicit does it need to be? Journal of Second Language Writing, 10, 161-184.

Ferris, D. R., Liu, H., \& Rabie, B. (2001). "The job of teaching writing": Teacher views of responding to student writing. Writing and Pedagogy, 3(1), 39-77.

Furneaux, C., Paran, A., \& Fairfax, B. (2007). Teacher stance as reflected in feedback on student writing: An empirical study of secondary school teachers in five countries. International Review of Applied Linguistics in Language Teaching, 45, 6994.

Gass, S., \& Selinker, L. (1994). Second language acquisition: An introductory course. Hillsdale: Lawrence Erlbaum Associates.

Gholaminia, I., Gholaminia, A., \& Marzban, A. (2014). An investigation of meta-linguistic corrective feedback in writing performance. Procedia - Social and Behavioural Sciences, 116, 316-320.

Hattie, J.A.(1999, August). Influences on student learning (Inaugural professorial address, University of Auckland, New Zealand). Retrieved from https://cdn.auckland.ac.nz/assets/education/ about/research/documents/influences-on-student-learning.pdf

Hattie, J., \& Timperley, H. (2007). The power of feedback. Review of Educational Research, 77(1), 81-112. https://doi. org/10.3102/003465430298487 
Hedgcock, J., \& Lefkowitz, N. (1994). Feedback on feedback: Assessing learning receptivity to teacher response in L2 composing. Journal of Second Language Writing, 3, 141163.

Hendrickson, J. M. (1980). The treatment of error in written work. Modern Language Journal, 64, 216-221.

Hosseiny, M. (2014). The role of direct and indirect written corrective feedback in improving Iranian EFL students' writing skill. Procedia - Social and Behavioural Sciences, 98, 668-674.

Hyland, F. (1998). The impact of teacher written feedback on individual writers. Journal of Second Language Writing, 7, 255-286.

Hyland, F. (2003). Focusing on form: Student engagement with teacher feedback. System, 31(2), 217-230.

Hyland, F. (2010). Future directions in feedback on second language writing: Overview and research agenda. International Journal of English Studies, 10(2), 173-182.

Jamalinesari, A., Rahimi, F., Gowhary, H., \& Azizifar, A. (2015). The effects of teacher-written direct vs. indirect feedback on students' writing. Procedia-Social and Behavioural Sciences, 192, 116-123. https://doi.org/10.1016/j.sbspro.2015.06.018

Karim, K. (2013). The effects of direct and indirect written corrective feedback (CF) on English-as-a second language (ESL) students' revision accuracy and writing skills (Unpublished doctoral dissertation). University of Victoria, Canada.

Kepner, C. G. (1991). An experiment in the relationship of types of written feedback to the development of second language writing skills. Modern Language Journal, 75, 305-313.

Köksal,D., Özdemir, E., Tercan, G., Gün, S., \& Bilgin, E. (2018). The relationship between teachers' written feedback preferences, self-efficacy beliefs and burnout levels. Journal of Language and Linguistic Studies, 14(4), 316-327.

Lalande, J. (1982). Reducing composition error: An experiment. Modern Language Journal, 66, 140-149.

Lee, I. (2005). Error correction in the L2 classroom: What do students think? TESL Canada Journal, 22, 1-16.

Lee, L. (2008). Focus-on-form through collaborative scaffolding in expert-to-novice online interaction. Language Learning and Technology, 12(3), 53-72.

Leki, I. (1991). The preferences of ESL students for error correction in college level writing classes. Foreign Language Annals, 24, 203-218. 
Li, H., \& He, Q. (2017). Chinese secondary EFL learners' and teachers' preferences for types of written corrective feedback. English Language Teaching, 10(3), 63-73.

Liu, S., \& Jhaveri, A. (2019). Improving grammatical accuracy through written corrective feedback (WCF). Paper presented at The University of Hong Kong HKCPD Symposium 2019, Hong Kong.

Long, M., \& Robinson, P. (1998). Focus on form: Theory, research and practice. In C. Doughty, \& J. Williams (Eds.), Focus on form in classroom second language acquisition. Cambridge, UK: Cambridge University Press.

Long, M. (2000). Focus on form in task-based language teaching. In R.D. Lambert \& E. Shohamy (Eds.), Language Policy and Pedagogy: Essays in honor of A. Ronald Walton, Philadelphia: John Benjamins.

Lyster, R. (2007). Learning and teaching languages through content: A counterbalanced approach. Philadelphia: John Benjamins. https://doi.org/10.1075/1llt.18

Makino, T. Y. (1993). Learner self-correction in EFL written compositions. ELT Journal, 47, 337-341.

Mao, S. S., \& Crosthwaite, P. (2019). Investigating written corrective feedback: (Mis)alignment of teachers' beliefs and practice. Journal of Second Language Writing, 45, 46-60.

McCargar, D. (1993). Teacher and student role expectations: Crosscultural differences and implications. The Modern Language Journal, 77, 192-207.

McKinley, J. (2015). Critical argument and writer identity: Social constructivism as a theoretical framework for efl academic writing. Critical Inquiry in Language Studies, 12(3), 184-207. doi: 10.1080/15427587.2015.1060558

McLeod, S. (2019, July 17). Constructivism as a theory for teaching and learning. Retrieved from https://www.simplypsychology. org/constructivism.html

Ministry of Education Malaysia (2013). Malaysia Education Blueprint 2013-2025 (Preschool to Post-Secondary Education). Putrajaya: Kementerian Pendidikan Malaysia.

Mollestam, E., \& Hu, L. (2016). Corrective feedback on L2 students' writing. Malmö högskola/Lärande och samhälle. Retrieved from http://hdl.handle.net/2043/20687

Nair, G. K. S., Rahim, R. A., Setia, R., Husin, N., Sabapathy, E., Jalil, N. A. A., ... Seman, N. A. (2012). Malaysian graduates English adequacy in the job sector. Asian Social Science, 8(4), 143-147. 
Paulus, T. M. (1999). The effect of peer and teacher feedback on student writing. Journal of Second Language Writing, 8, 265289.

Poorebrahim,F.(2017).Indirect written corrective feedback, revision, and learning. Indonesian Journal of Applied Linguistics, 6(2), 184-192.

Rahim, S. A., Jaganathan, P., \& Mahadi, T. S. T. (2019). Students' experiences in L2 writing and their opinion on written corrective feedback. International Journal of Languages, Literacies and Translation, 2(1), 68-76.

Raimes, A. (1991). Errors: Windows into the mind. College ESL, $1(2), 55-64$.

Reid, J. (1993). Teaching ESL writing. New Jersey: Prentice Hall Regents.

Rezazadeh, S., Ashrafi, S., \& Foozunfar, M. (2018). The Effects of Oral, Written Feedback Types on EFL Learners' Written Accuracy: The Relevance of Learners' Perceptions. Paper presented at the Second National Conference on English Language Studies: Applied Linguistics Perspectives on EFL, Azerbaijan.

Ruegg,R.(2010).Interlanguage development: The effect of unfocused feedback on L2 writing. Intercultural Communication Studies, 19(1), 247-254.

Russell, J., \& Spada, N. (2006). The effectiveness of corrective feedback for the acquisition of L2 grammar. In Norris, J. (Ed.), Synthesizing Research on Language Learning and Teaching. Philadelphia: John Benjamins.

Saeli, H. (2019). Teachers' practices and students' preferences: Grammar-centered written corrective feedback in Iran. Research in English Language Pedagogy, 7(1), 46-70.

Sauro, S. (2009). Computer-mediated corrective feedback and the development of L2 grammar. Language Learning \& Technology, 13(1), 96-120.

Schulz, R. A. (2001). Cultural differences in student and teacher perceptions concerning the role of grammar instruction and corrective feedback: USA-Columbia. Modern Language Journal, 85, 244-258.

Segalowitz, N. (2000). Automaticity and attentional skill in fluent performance. In H. Riggenbach (Ed.) Perspectives on Fluency, 200-219. Ann Arbor MI: The University of Michigan Press.

Sheen, Y. (2007). The effect of focused written corrective feedback and language aptitude on ESL learners' acquisition of articles. TESOL Quarterly, 41, 255-283. 
Sheen, Y. (2011). Corrective feedback, individual differences and second language learning. Netherlands: Springer.

Sheppard,K. (1992). Two feedback types: Do they make a difference? RELC Journal, 23(1), 103-110.

Shintani, N., Ellis, R. \& Suzuki, W. (2014). Effects of written feedback and revision on learners' accuracy in using two English grammatical structures. Language Learning, 64, 103131. https://doi.org/10.1111/lang.12029

Sullivan, N., \& Pratt, E. (1996). A comparative study of two ESL writing environments: A computer assisted classroom and a traditional oral classroom. System, 29(4), 491-501.

Swain, M. (1985). Communicative competence: Some roles of comprehensible input and comprehensible output in its development. In S. M. Gass \& C. G. Madden (Eds.), Input in second language acquisition (pp. 235-253). Massachusetts: Newbury House.

Sweller, J. (1988). Cognitive load during problem solving: Effects on learning. Cognitive Science, 12, 257-285.

Tafazoli, D., Nosratzadeh, H., \& Hosseini, N. (2014). Computermediated corrective feedback in ESP courses: Reducing grammatical errors via Email. Procedia - Social and Behavioural Sciences, 136, 355-359.

Tanveer, A., Malghani, M., Khosa D., \& Khosa, M. (2018). Efficacy of written corrective feedback as a tool to reduce learners' errors on L2 writing. International Journal of English Linguistics, 8(5), 166-180.

Truscott, J. (1996). The case against grammar correction in L2 writing classes. Language Learning, 46, 327-369.

Truscott, J. (1999). The case for "The case against grammar correction in L2 writing classes": A response to Ferris. Journal of Second Language Writing, 8(2), 111-122.

Truscott, J. (2004). Evidence and conjecture on the effects of correction: A response to Chandler. Journal of Second Language Writing, 13(4), 337-343.

Truscott, J. (2007). The effect of error correction on learners' ability to write accurately. Journal of Second Language Writing, 16, 255-272.

Truscott, J. (2009). Arguments and appearances: A response to Chandler. Journal of Second Language Writing, 19(1), 5960 .

Truscott, J. (2010). Some thoughts on Anthony Bruton's critique of the correction debate. System 38(2), 329-335. 
Tuzi, F. (2004). The impact of e-feedback on the revisions of L2 writers in an academic writing course. Computers and Composition, 21(2), 217-235.

Ur, P. (1996). A course in language teaching: Practice \& theory. Cambridge: Cambridge University Press.

Van Beuningen, C. G., de Jong, N. H., \& Kuiken, F. (2008). The effect of direct and indirect corrective feedback on L2 learner's written accuracy. International Journal of Applied Linguistics, 156, 279-296.

Voerman, L., Meijer, P. C., Korthagen, F. A. J., \& Simons, R. J. (2012). Types and frequencies of feedback interventions in classroom interaction in secondary education. Teaching and Teacher Education, 28, 1107-1115.

Vygotsky, L. S. (1978). Mind in society: The development of higher psychological processes. Massachusetts: Harvard University Press.

Ware, P. D., \& Warschauer, M. (2006). Electronic feedback and second language writing. In Hyland, K., \& Hyland, F. (Eds), Feedback in second language writing: Contexts and issues (pp. 105-122). Cambridge: Cambridge University Press.

Westmacott, A. (2017). Direct vs. indirect written corrective feedback: Student perceptions. Íkala, Revista de Lenguaje y Cultura, 22(1), 17-32.

Woroniecka, I. (1998). A nonnative student's reactions to instructors' feedback on his papers: A case study of an undergraduate history student (Unpublished Master's thesis). University of Toronto, Canada. Retrieved from http://www.nlcbnc.ca/obj/ s4/f2/dsk1/tape11/PQDD_0004/MQ40680.pdf

Zamel, V. (1985). Responding to student writing. TESOL Quarterly, 19, 79-101. 